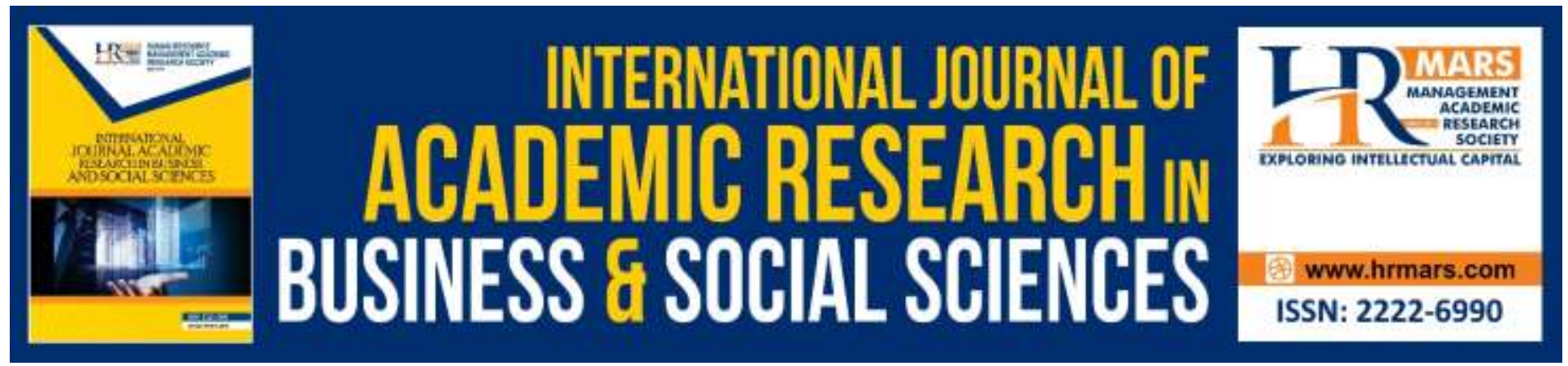

\title{
A Preliminary Study on the Elements of Hisbah in Islamic Psychology
}

Afifi Farhana Mhd Poad, Azrin Ibrahim

To Link this Article: http://dx.doi.org/10.6007/IJARBSS/v9-i11/6588

DOI: 10.6007/IJARBSS/v9-i11/6588

Received: 10 October 2019, Revised: 30 October 2019, Accepted: 03 November 2019

Published Online: 13 November 2019

In-Text Citation: (Ling et al, 2019)

To Cite this Article: Poad, A. F. M., Ibrahim, A. (2019). A Preliminary Study on the Elements of Hisbah in Islamic Psychology. International Journal of Academic Research in Business and Social Sciences, 9(11), 664-672.

Copyright: (C) 2019 The Author(s)

Published by Human Resource Management Academic Research Society (www.hrmars.com)

This article is published under the Creative Commons Attribution (CC BY 4.0) license. Anyone may reproduce, distribute, translate and create derivative works of this article (for both commercial and non-commercial purposes), subject to full attribution to the original publication and authors. The full terms of this license may be seen at: http://creativecommons.org/licences/by/4.0/legalcode

Vol. 9, No. 11, 2019, Pg. 664 - 672

http://hrmars.com/index.php/pages/detail/IJARBSS

JOURNAL HOMEPAGE

Full Terms \& Conditions of access and use can be found at http://hrmars.com/index.php/pages/detail/publication-ethics 


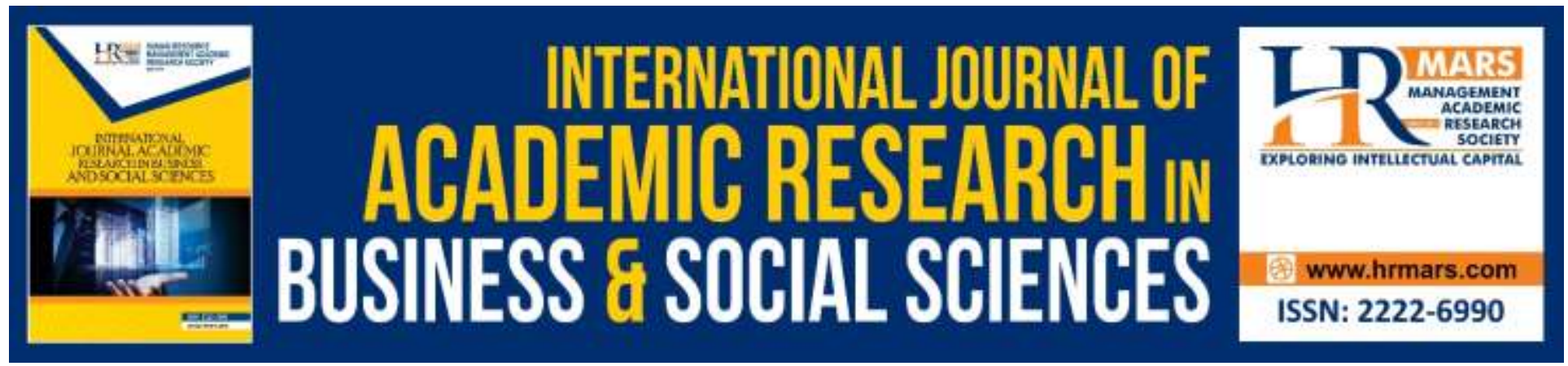

\title{
A Preliminary Study on the Elements of Hisbah in Islamic Psychology
}

\author{
Afifi Farhana Mhd Poad, Azrin Ibrahim \\ Centre for Islamic Development Management Studies (ISDEV), Universiti Sains Malaysia, 11800 \\ Pulau Pinang, Malaysia \\ Email: afififarhana@Yahoo.Com
}

\begin{abstract}
Islamic psychology is a branch of knowledge that is often debated and discussed by Muslim scholars. One reason has to do with the fact that the knowledge of Islamic psychology is complex. It does not only discuss the knowledge of the soul but it also involves the heart, lust, soul and mind that function to monitor human behavior. According to al-Ghazali, the knowledge about the soul and this human component is inseparable with hisbah. The question is, is there the element of hisbah or monitoring in Islamic psychology that acts to monitor all forms of human behavior mentally and physically? To answer this, this study carries two main objectives which is, firstly; to identify Islamic psychology, secondly, to analyse the element of hisbah in Islamic psychology from previous studies. Thus, this study employs the qualitative study design through document study. After that, the data obtained through the document study will be analysed using the content analysis method. The study finding establishes that there is the element of hisbah in Islamic psychology in several past studies that have been discussed. Among them is through the component of Islamic psychology itself, comprising of an-nafs which is able to control the individual from doing anything forbidden in Islam.
\end{abstract}

Keywords: Hisbah, Islamic Psychology

\section{Introduction}

The studies about Islamic psychology and hisbah are often the matter of concern among previous scholars or contemporary researchers. However, both the studies have been done separately from one another. Researcher finds that psychology and hisbah share the same aim which is to generate some actions, be it good behavior or emotions for the sake of Allah SWT. Therefore, this paper work aims to identify the element of hisbah in Islamic psychology based on the works carried out by previous scholars. The structure of this paper work is divided into three parts. The first part discusses the basic concept of Islamic psychology and hisbah. The second part focuses 
on the analysis of the element of hisbah in Islamic psychology based on past literature. Finally, the third part concludes the entire paper work. However, this paper work only refers to the study published eight years ago, beginning from the year 2012 to 2019. As the result, there is the element of hisbah in Islamic psychology that is able to conclude the fact that Islamic psychology is one of the monitoring agents of human behavior.

\section{Literature Review}

Etymologically, the word 'psychology' comes from Greek psyche meaning 'soul' and logos meaning 'knowledge' (Munn, 1962; Mboga, Ondondo \& Ongarora, 2019). Thus, psychology is generally the knowledge about the soul encompassing the behavior, thinking and feelings of an individual. Islamic psychology is the knowledge about the soul that leans on the Muslim shari'a which includes the spiritual and the physical. (Mujib, 2005; Jabar \& Ahmad, 2018). If we look into the views of the Muslim scholars, Islamic psychology has four main elements relating the knowledge of the soul namely al-qalb, al-ruh, al-nafs dan al-aql (al-Ghazali, 1966; Ibrahim, 2018; Riaz, Hongbing, Hashmi, Khan, 2018). The element of Islamic psychology guided upon this spiritual element is seen to be able to control human behavior to ensure that every action can be done properly. Thus, Islamic psychology is a field that can control human behavior in guaranteeing that every action fits the shari'a of Islam and continues to achieve the mercy of Allah SWT.

Monitoring in Islam is known as hisbah which is an activity done by Rasulullah SAW to monitor the activities of the traders in the market during his early rule in Medina. Hisbah is basically an Arabic word (ihtisaban, yahtasibu and ihtisaban) which means pursuing to attain Allah's rewards by doing all the good things as commanded in Islam (Ibn-Manzur, 1997). As a term, hisbah is known as the act of urging people to do good things when humans stop doing bad things, and vice versa (al-Mawardi, 1993).

Hisbah comprises of four main principles namely Allah SWT's supervision, reasonable punishment, the responsibilities to do what one is obliged to do, carrying the mandate and the obligation towards doing good deeds and not committing bad deeds (Abdullah, 2000; Makhsin, 2008). According to Abdullah (2000) and Ibrahim (2019), the most absolute and the highest element in an individual is the monitoring of Allah SWT. Thus, a monitoring will not be achieved by only taking guidance from the country, institution or organization as an individual is also subject to Allah's monitoring and control.

However, to ensure that the principle of hibah can achieved, there are several processes that can take place. As put forth by al-Ghazali (1968), Abdullah (2000), Makhsin (2008), YaPEIM (2010) and Aziz (2015) state that the hibah process comprises of musyaratah ${ }^{1}$, muraqabah ${ }^{2}$,

\footnotetext{
${ }^{1}$ Musyaratah means having the determination in our hearts (al-Ghazali, 1698; Auni Abdullah, 2000).

2 Muraqabah means being careful towards any spiritual diseases that exist within us (alGhazali, 1968; Hawa, 2001).
} 
INTERNATIONAL JOURNAL OF ACADEMIC RESEARCH IN BUSINESS AND SOCIAL SCIENCES

Vol. 9, No. 11, November, 2019, E-ISSN: 2222-6990 @ 2019 HRMARS

muhasabah $^{3}, m^{\prime} a q a b a h^{4}$, mujahadah ${ }^{5}$ also mu'atabah $^{6}$ This process can also prevent and free an individual from traits of mazmumah spurred by negative characteristics like lazy attitude and being deviant. This kind of monitoring will yield the best attitude from every individual. Thus, the following subtopic will attempt to analyse the element of hisbah in Islamic psychology in further detail.

\section{The Analysis of the Elements of Hisbah in Islamic Psychology}

As the previous literature is analysed, it shows that Islamic psychology plays the role of hisbah which is monitoring human actions and thinking so they go hand in hand with the laws of Islam or the shari'a of Islam. Based on the work by Haque (2018), Skinner (2018), Rothman and Coyle (2018) also Khalid Qureshi and Rehman (2015) Islamic psychology is identified to cover the elements of nafs, ruh, qalb, aql'. The work of Skinner (2018), Rothman and Coyle (2018) and Qureshi and Rehman (2015) establish that the nafs, ruh, qalb dan aql' are very much linked with $a_{m m a r a h^{7}}$, lawwamah ${ }^{8}$ and mutmainnah ${ }^{9}$. According to Qureshi and Rehman (2015) it is a level of human stages that can determine if humans can control himself from doing good or bad deeds. Therefore, to yield some positive impact on the element of psychology, Amber Haque (2018) has listed six models of self enhancement based on the methods given by al-Ghazali which comprise of musyaratah, muraqabah, muhasabah, mu'aqabah, mujahadah and mu'atabah. It was the same model introduced by Mujib (2015) although his model focuses on Islamic personality through the psychosufistic approach. Through his work, it is found that humans need to undergo the process of tazkiyah an-nafs supported by seven stages of inner cleansing namely musyaratah, muraqabah, muhasabah, mu'aqabah, mujahadah, mu'atabah and mukasyafah. The work by Sa'ari and Muhsin (2012) also maintains that one has to control lust through tazkiyah an-nafs

${ }^{3}$ Muhasabah is the process of self-analysing on the tasks done and quickly improves it and having the determination to strengthen his relationship with Allah SWT (Ahmad, 1998).

${ }^{4} M$ M $^{\prime} a q a b a h$ is the evaluation of the work done by observing the weakness or flaws in his action or practice (Sa'id Hawa, 2001; Ahmad Bashir Aziz, 2015).

${ }^{5}$ Mujahadah means really fighting on the path of Allah SWT without having the fear towards any threat from other parties (al-Ghazali, 1968; Hawa, 2001).

${ }^{6} \mathrm{Mu}$ 'atabah is the process of self-criticism until one feels regretful towards the mistake one commits (al-Ghazali, 1968; Makhsin, 2008).

7 ammarah is the lowest human phase - it is a negative value and one that always deviates from Allah SWT (Yasien Mohamed, 1986).

8 lawwamah is the lust that directs one to do good - it is between negative and positive tendencies (Yasien Mohamed, 1986).

${ }^{9}$ mutmainnah is the highest phase of lust and it is free from evil, negative deeds (Yasien Mohamed, 1986). Nonetheless, according to Muhammad Syukri Salleh (2003) human lust comes in seven phases namely ammarah, lawwamah, mulhamah which is of negative value (mazmumah) mutmainnah, radhiyah, mardhiyyah and kamilah a good form of lust (mahmudah). 
which is the method of cleansing one's soul with negative attributes which is a transitional process from a dirty soul to a clean one, to ensure that every action done will be in line with the Shari'a of Islam.

Apart from that, the study by Rothman dan Coyle (2018) also mentions about tazkiyah an-nafs in the model of the soul that is developed as the process of soul development together with jihad an-nafs (battling with oneself) and tahdib al-akhlaq (improving one's character) in the process. This will determine the goodness (munjiyat) and evil (muhlikat) of a person and it can ensure that the individual is fit to obtain Allah's blessings, or otherwise (Rothman \& Coyle, 2018). This is closely associated with the process of hisbah which is a step to control one from doing bad things and preventing people from deviating from the shari'a of Islam. Figure 1 are the psychoanalytic models presented by Rothman and Coyle (2018):

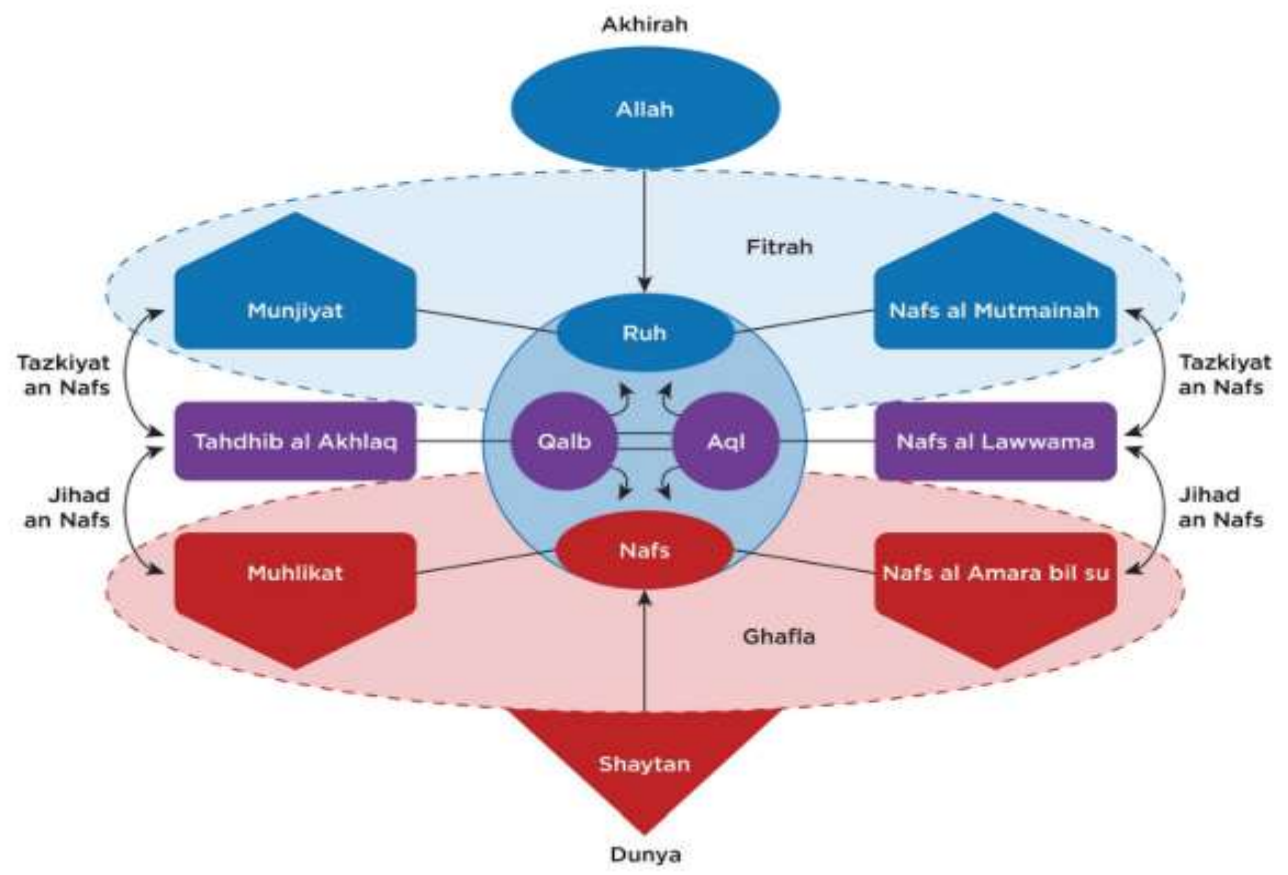

Figure 1: Model of the soul according to Rothman \& Coyle (2018)

The same goes with the work done by Md Sham (2016) who discusses mujahadah an-nafs or fighting against the lust to generate good behavior. She states that Islamic psychology stresses on the soul and the spiritual and they act to control one's behavior and tendency. However, the study by Skinner (2018) has put forth the traditional Islam through medicine and nutrition to weaken the nafs, also the behavior to train the anxiety, analysis or thinking that connect aql and $q a l b$ and it helps the $a q l$ to form several senses of control on nafs. Finally, through zikr and other acts of worship, it can also open the heart and broaden one's sense of control on the imbalance in $a q l$ and nafs.

Next, the work done by Khodayarifard et al., (2016) shows that the Islamic perspective covers three time scales namely events in the past, the present and the future which stress on human 
relationship with self, human with human, human with nature and human with Allah SWT in controlling one's spirituality. In hisbah, the relationship with Allah SWT is the most important element that generates the principle of the supervision of Allah SWT who controls humans in doing things, to the point that they have the desire to steer clear of Allah SWT's forbidden rules and to do the things He has commanded. From the study of Sanver (2013) a characteristic of positive human based on the psychology in the Quran is that man is the caliphs of Allah SWT responsible in educating themselves in doing what is required and preventing themselves from doing any bad actions. If we look at the element of hisbah, humans are held responsible to carry out the mandate that has been established since before birth. Next, the responsibility that one has to bear to do the makruf and avoid doing the mungkar leads to one being rewarded to obtain the mercy of Allah in the future or in the after-world.

Based on the work by Rezaeitalarposhti (2013), psychology from the perspective of the Quran discovers seven elements that exist in humans. The elements of fitra, self, spiritual or inner-self, lust, the balance between spiritual and physical, the spiritual continuance towards one's physicality or behavior and self-development. The spiritual continuance towards the physicality or behavior is linked closely with the process of hisbah that begins with the spiritual aspect of a good behavior. Based on the study by Bhat (2016) the spiritual dimension is the one that differentiates Islamic psychology and the Western psychology. As a human, it is normal for him or her to achieve life goals and to prevent oneself from negative attitudes. Humans are also granted the knowledge about ill deeds so that they can steer clear of wrongdoings in their lives and they can prevent others from doing them (Bhat, 2016).

Kemahli (2016) through his studies about human behavior based on the concept of qalb from the perspective of Al-Ghazali finds that the human heart has four basic categories namely animalistic instinct or lust, anger, divinity and evilness. According to him, the heart is the control center for human behavior. Thus, to make sure that the behavior is positive, one should control one's heart from doing bad deeds. This is consistent with the argument raised by Hidayat (2014) who finds that Islamic psychology holds the principle to explain, predict, control and direct to obtain the blessings of Allah SWT through deeds and knowledge. Following this, Islamic psychology is seen to have a relation to hisbah because hisbah is an aspect of control from doing deviant things or activities. In brief, the elements of Islam in Islamic psychology can be seen in the following figure 2: 


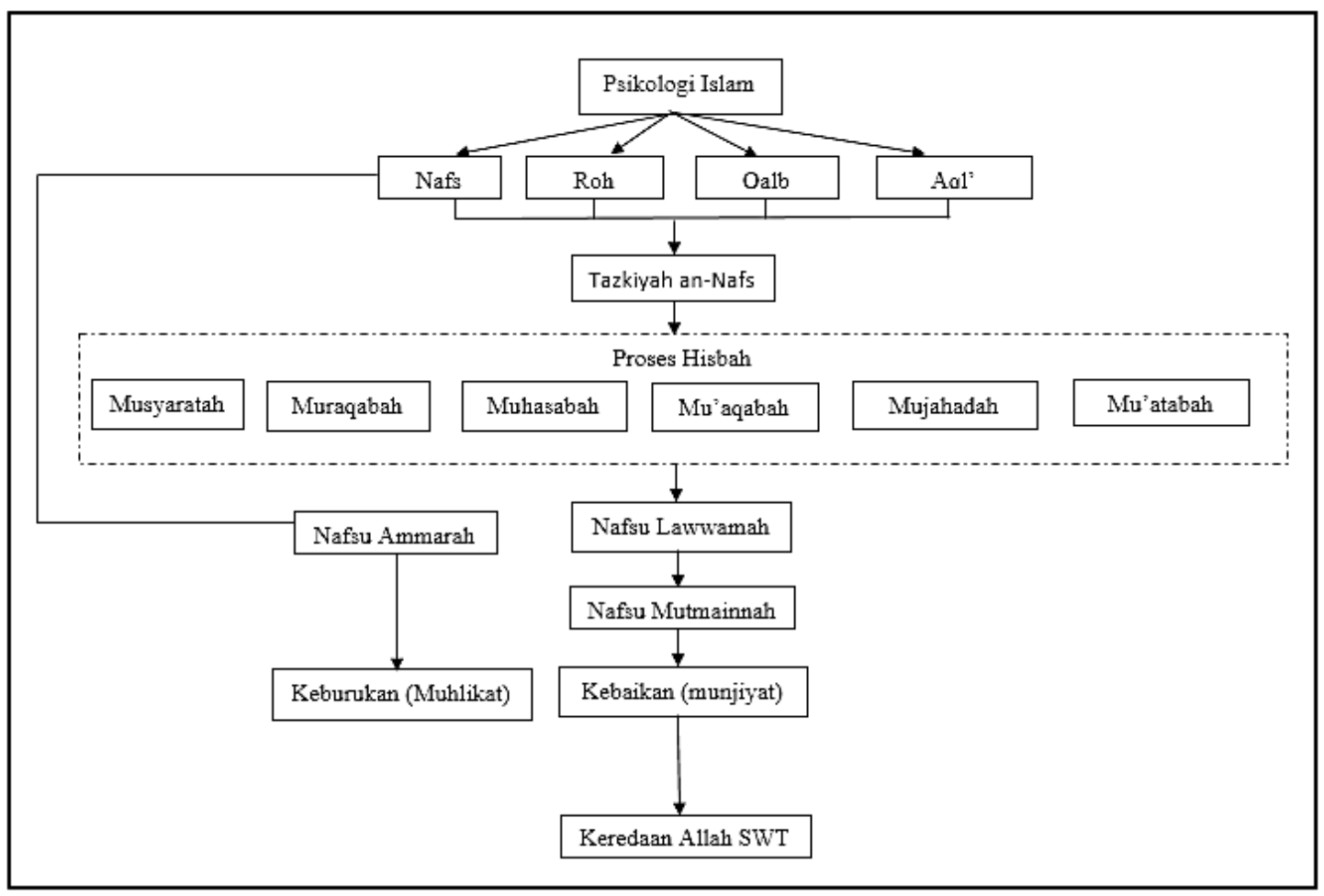

Figure 2: The Elements of Hisbah in Islamic Psychology

In sum, the element of hisbah in Islamic psychology is based on the elements of nafs, ruh, qalb and $a q l^{\prime}$. If these elements are complemented with cleansing and some control process, then good lusts such as lawwamah and mutmainnah shall prevail. The lusts will form good behavior, thinking, and feelings and consequently, one will attain the blessings of Allah SWT. That said, if one's lust is not handled very well, without some cleansing and control, negative lusts will surface, such as ammarah. This will be detrimental to one's behavior, thoughts and feelings.

\section{Conclusion}

Conclusively, Islamic psychology is a branch of knowledge that is closely associated with the spirit, the soul, the mind and the heart of man. All these four elements are prioritized in Islamic psychology because it is through these elements that form one's behavior. If they function well according to the Shari'a of Islam, one will act well too in his behavior or way of thinking. This is important to steer clear of bad deeds and it is able to invite other people to do good deeds as well. Therefore, Islamic psychology is seen to be related to the element of hisbah which seeks to control oneself and others from deviating and preventing oneself from doing bad or negative things through the processes of musyaratah, muraqabah, muhasabah, mu'aqabah, mujahadah, mu'atabah or tazkiyah an-nafs.

This is due to the fact that hisbah holds the principle that everything done is under the supervision of Allah SWT and humans will be judged accordingly. Therefore, one has to fulfill his 
obligation and mandate, also performs good deeds and prevents oneself from committing bad deeds. Thus, automatically the element of hisbah contained in the Islamic psychology has its main aim which is to generate positive behavior. This leads to why Islamic psychology and hisbah should be studied profoundly to make sure that this knowledge of Islam can be applied collectively and for it to be able create something better in life.

\section{Acknowledgement}

Thank you to the Universiti Sains Malaysia (USM) for research funding through Research University Individual (RUI) (1001/CISDEV/8016039) - Grant Title: Psycho-Hisbah Model for Performance Evaluation.

\section{References}

Aziz, A. B. (2015). Pengurusan Islam Alternatif Pengurusan Moden. Sintok: Universiti Utara Malaysia.

Al-Ghazali. (1968). Ihya' 'Ulumuddin. Kaherah: Mu'assasah Al-Halabi Wa Syurakah.

Al-Mawardi. (1993). Al-Ahkam al-Sultaniyyah wa al-Wiyah al-Diniyyah (Uthman Khalid, Terj). Kuala Lumpur: Institut Pengajian Tradisional Islam.

Abdullah, A. (2000). Hisbah dan pentadbiran negara. Kuala Lumpur: IKDAS Sdn Bhd.

Ibrahim, A., \& Poad, M. A. F. (2018). The Element of Self-Hisbah in Human Management Practices. International Journal of Academic Research in Business and Social Sciences, 8(11), 877-884.

Ibrahim, A. (2019). The fundamentals of hisbah strategic in developing of human civilization. Academy of Entrepreneurship Journal, V. 25 (1) 2019.

Bhat, A. M. (2016). Human psychology (fitrah) from Islamic perspective. International Journal of Nusantara Islam, 4(2), 61-74.sanver (2013).

Jabar, S. A., \& Ahmad, A. C. (2018). The Design of Multimedia Interactive Courseware for Teaching Reading to Hearing Impaired Students. International Journal of Academic Research in Progressive Education and Development, 7(4), 223-230.

Sa'ari, C. Z. \& Muhsin, S. B. (2012). Cadangan model psikoterapi remaja Islam berasaskan konsep tazkiyah al-Nafs. Jurnal Usuluddin, (36), 49-74.

Sham, F. (2016). Elemen psikologi Islam dalam silibus psikologi moden: Satu alternatif. Global Journal Al-Thaqafah (GJAT), 6(1), 75-85. Retrieved from www.gjat.my

HAMKA. (1990). Tafsir al-Azhar. Singapura: Pustaka Nasional Pte Ltd.

Haque, A. (2018). Psychology from an Islamic perspective. Global Psychologies, 137-150. Hidayat, B. (2014). Psikologi Islam. https://doi.org/10.13140/RG.2.2.22333.15845.

Ibn-Manzur. (1997). Lisan al-arab. Beirut: Dar Ihya' Al-Turath Al-'Arabiy.

Kemahlı, H. P. (2017). Four inclinations in human nature: evaluated in light of Al-Ghazzali's concept of the heart. Spiritual Psychology and Counseling, 2(1), 9-30. https://doi.org/10.1007/s10971-010-2392-5 
INTERNATIONAL JOURNAL OF ACADEMIC RESEARCH IN BUSINESS AND SOCIAL SCIENCES

Vol. 9, No. 11, November, 2019, E-ISSN: 2222-6990 ㄷ 2019 HRMARS

Khodayarifard, M., Ghobari-bonab, B., Akbari-zardkhaneh, S., \& Zandi, S. (2016). Positive psychology from Islamic perspective. International Jurnal of Behaviour Science, 2(July), 77-83.

Makhsin, M. (2008). Hisbah Sistem Pengawasan Dan Etika Pengurusan Islam. Sintok: Universiti Utara Malaysia.

Salleh, M. S. (2003). 7 Prinsip Pembangunan Berteraskan Islam. Kuala Lumpur: Zebra Editions Sdn. Bhd. \& Pulau Pinang: Projek Sains Kemasyarakatan, Universiti Sains Malaysia.

Mboga, J. M. Ondondo, E. A., \& Ongarora, D. O. (2019). Ekegusii Subject And Object Markers: Affixes Or Clitics?. Multilingual Academic Journal of Education and Social Sciences, 7(1), 132-152.

Mujib, A. (2015). Model kepribadian Islam melalui pendekatan psikosufistik. Nuansa, VIII (1), 5160.

Munn, L. N. (1962). Introduction to Psychology. Boston: Houghton Mifflin Company.

Yapeim. (2010). Pengurusan Islami Menghayati Prinsip Dan Nilai Qurani. Kuala Lumpur: Akademi Pengurusan YaPEIM.

Qureshi, R. K., \& Rehman, Q. H. (2015). Islam and human psychology. Pakistan Journal of Commerce and Social Sciences, 9(3), 1012-1016.

Rezaeitalarposhti, A. A., \& Rezaeitalarposhti, A. A. (2013). Psychology from Islamic perspective: Contributions of quran to contemporary psychologists. International Research Journal of Applied and Basic Sciences, 6(11), 15901595. http://www.irjabs.com/files_site/paperlist/r_1865_131119162251.pdf

Rothman, A., \& Coyle, A. (2018). Toward a framework for Islamic psychology and psychotherapy: An Islamic model of the soul. Journal of Religion and Health, 57(5), 1731-1744. https://doi.org/10.1007/s10943-018-0651-x.

Qutb, S. (2000). Tafsir fizilalil Quran. (Yussof Zaky Yacob, Terj). Kelantan: Pustaka Aman Press Sdn Bhd.

Riaz, A., Hongbing, O., Hashmi, S.H. Khan, M.A. (2018). The Impact of Economic Policy Uncertainty on US Transportation Sector Stock Returns, International Journal of Academic Research in Accounting, Finance and Management Sciences 8 (4): 163-170.

Skinner, R. (2018). Traditions, paradigms and basic concepts in Islamic psychology. Journal of Religion and Health. https://doi.org/10.1007/s10943-018-0595-1.

Mohamed, Y. (1986). The Islamic conception of human nature with special reference to the development of an Islamic psychology. Disertasi yang diserahkan kepada University of Cape Town. 